\title{
Poesía gráfica
}

\section{Graphic poetry}

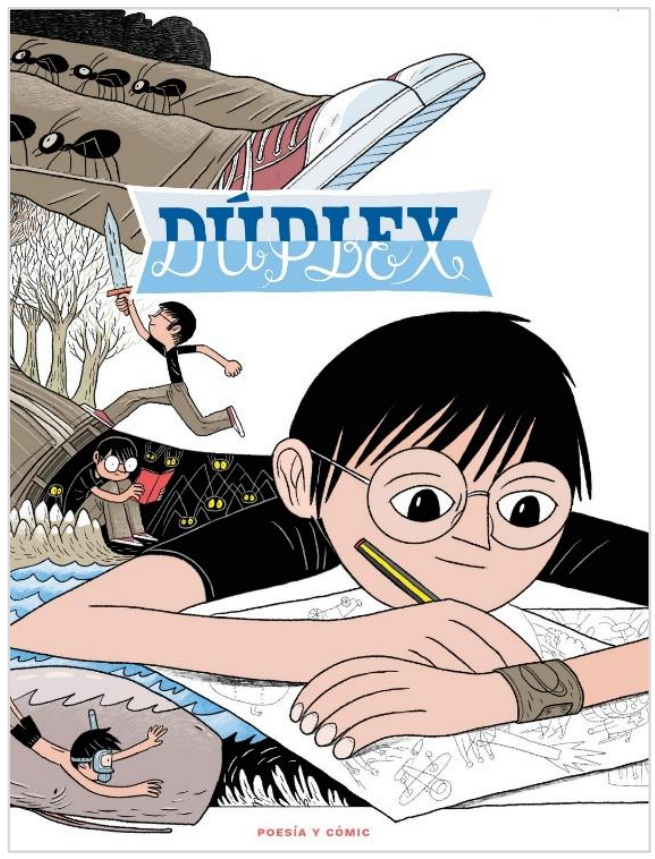

Reseña de: Del Rey Cabero, E. Y SÁez de AdAna, F. (eds.), Dúplex. Poesía y cómic, Marmotilla, Alas Ediciones, 2019.

\section{José Manuel Trabado Cabado \\ Universidad de León jmtrac@unileon.es \\ Código ORCID: https://orcid.org/0000-0002- 9072-7435}

Referencia: TRABADO CABADO, J. M., «Poesía gráfica», Neuróptica. Estudios sobre el cómic, segunda época, 2, Zaragoza, Prensas de la Universidad de Zaragoza, 2020, pp. 277-282.

En el marco de este libro colectivo tiene lugar un encuentro que, $a$ priori, era poco previsible: el de la poesía y el del cómic. La lírica ha tenido un difícil encaje dentro de las propuestas teóricas ya desde las reflexiones más tempranas: la dificultad de aquilatar su entidad ficticia, por un lado, y la refracción a valerse de un argumento para naturalizar su textualidad, por otro lado, la apartaban de las ideas aristotélicas de la mímesis de una acción. Todos aquellos tratadistas neoaristotélicos tuvieron que hacer en el siglo XVI un ejercicio de equilibrios muy inestables para conseguir introducir dentro del entramado teórico una práctica como la lírica, plenamente asentada en la práctica, pero de difícil deglución en las poéticas. Ahí ha estado una de las grandes dialécticas del pensamiento teórico literario que partía de la necesidad de ir justificando prácticas consolidadas, y otras no tanto por su novedad, dentro de un esquema forjado hace siglos que no contemplaba en sus esquemas casillas para casos como el de la lírica o la novella. Genette y Gamoneda, cada uno desde su ladera, han problematizado el género lírico y, bien o lo han sacado del territorio de la literatura o bien le han negado el 
estatus de ficción. Todo ello da muestras de la complejidad de la poesía en su concepción genérica.

En el otro lado de la balanza que plantea Dúplex está el lenguaje del cómic, que se ha venido aferrando a una narratividad asociada a la lectura secuencial de imágenes. Cierto es que hay prácticas en la creación del cómic que han diluido ese componente argumental y cierto también que algunos planteamientos teóricos llevan a desmontar esa idea o, al menos, a darle menos peso específico en la caracterización del cómic. Existen trabajos que inciden en esa naturaleza de lo lírico asociado al lenguaje del cómic, como la apasionante tesis de Tamaryn Bennet, Comics Poetry. Beoynd the Sequential Boundaries o el número monográfico de Tebeosfera. 12. Poesía gráfica (2019) dedicado precisamente a este aspecto y coordinado por Álvaro Pons. Precisamente en este número aparece un texto firmado por Enrique del Rey, Francisco Sáez de Adana y Stefan Nieuwenhuis en el que se da noticia de un proyecto de cariz internacional denominado Duplex cuyo fin era poner en contacto a poetas con dibujantes de cómic para establecer entre ellos un diálogo poco habitual.

Tras una primera experiencia surgida en los Países Bajos en 2016 que fructifica en una antología cuyo título portaba ya esa dualidad Duplex, le sigue otra dos años más tarde que tendrá como colofón editorial Duplex Extra. British Poets and Artists (2018). Este volumen, como el lector posiblemente adivine ya, es el tercer paso en ese proyecto internacional que tiene ahora su parada en España. La dinámica pasa a ser básicamente la misma y poeta y dibujante colaboran en la creación de un trabajo que avanza en ese doble lenguaje de los versos y las viñetas. Es justo, y también necesario, recordar ahora el trabajo de autores como Miguelanxo Prado o Laura Pérez Vernetti que se han afanado por ligar la lírica al lenguaje del cómic. El inicio de Ardalén supone una sabia simbiosis de lirismo y plasticidad pictórica en forma de relato secuencial; Laura, por su parte, ha mostrado un entusiasmo encomiable a la hora de transformar poemas en viñetas, tal y como demuestran, entre otras obras, Ocho poemas (2016) en la que se encuentra un ejemplo maravilloso de la adaptación del poema de Menchu Gutiérrez «La escritura del pájaro». Ese deambular entre lírica y viñeta tiene en La cólera de Baudelaire (2020) su muestra más reciente. Son tan solo pequeñas muestras de esa nueva vía de exploración que merecen una atención. Tampoco está de más recordar el hecho de que esa secuencialidad del cómic lleva implícito un ritmo y que la poesía tiene, a su vez, una relación especial intensa con la repetición de patrones acentuales y sonoros. Baste recordar también que Chris Ware 
hablaba de un ritmo musical para sus viñetas. Como se puede ver, el mapa que va dibujándose es verdaderamente estimulante.

Metidos ya dentro de las páginas de Dúplex encontramos una variedad de propuestas que suponen una apertura digna de ser tenida en cuenta en lo que se refiere a los procedimientos expresivos del cómic. Los poemas de Ana Merino y el dibujo de Sergio García, que abren el volumen, establecen una perfecta complementariedad. Reconocibles son algunos de los elementos del repertorio tan personal de Sergio García y la ilustración que acompaña a «Salvamento de hormigas» de Ana Merino recuerda en su perspectiva contrapicada a la imponente adaptación que realizó sobre la obra de Alicia en el país de las maravillas para The New York Times. Es posible encontrarse en la imagen de «Retrato del dibujante» rastros de las teorías de Sergio y su idea de los contenedores de historias; uno puede ver, además, ciertas resonancias de otras obras del propio autor que ha ido forjando un estilo con una poderosa personalidad. Su imaginación, apabullante, está a la altura de los textos de Ana Merino.

Fernando Llorente de la Peña y Pablo García Moral entrelazan sus discursos en «Siroco en el refugio». La dureza temática del texto se acrisola sobre un relato casi de naturaleza fantástica en las palabras de Fernando Llorente. Pablo convierte la «niebla ocre» en sinuoso mosaico en el que parece entreverse un tríptico de orden narrativo. Por su parte, «Buckley's or none», cuyo guion es de Félix Vera y el dibujo de Maribel Conejero, tiene en el apartado gráfico una doble dinámica de enorme interés alternando primeros planos que se recortan a modo viñetas y se leen desde esa consabida secuencialidad con una representación cartográfica en la que se describe el deambular del personaje sobre un territorio. «Arden las cuerdas» de Diego Emiliano Garrido Stratta y Lucas Carillo presenta un poderoso andamiaje gráfico narrativo en el que no existen viñetas y las imágenes se funden en un todo contundente recordando las mejores páginas de aquellas revistas del boom de los años 80 .

De otro tenor es la colaboración de Óscar Rodríguez Martínez y Marta Cartu en «Expulsado». En este caso la narración gráfica se bifurca en dos líneas. Una de ellas bebe de la iconografía de la ciencia ficción y en ella se va situando superpuesto el texto En otra se observan pequeñas viñetas de naturaleza críptica que van esencializando (acaso esa pueda ser una de la cualidades de la lírica) el discurso. La paleta cromática y los recursos están en sintonía con los usados por alguien como Ana Galvañ y van dejando un cuidado diseño lleno de imágenes de potente plasticidad. El caso del texto «El 
jardín deshabitado» merecía páginas y páginas. Sobre el poema de Juanlu Mora, Zer (nombre de guerra de Sergio Arredondo) traza una lectura muy eficaz, de naturaleza conceptual, en el que un mismo hecho está visto desde una doble perspectiva. Ese azar traducido gráficamente en una moneda (que puede ser cara o cruz) despliega un doble discurrir de la historia. Son dos caminos antitéticos con finales también enfrentados. Esa dualidad no es tan explícita en el texto (incluso está por ver si existe) pero en el dibujo genera una idea de simultaneidad y caminos que se bifurcan en la que existen aportes gráficos de enorme rendimiento como son los pictogramas que encabezan cada escena. Resumiendo: una verdadera delicia.

8:45 es un texto de Gabriel Esmero que cuenta con el dibujo de Coralí Espuña. Ambos resuelven esa dialéctica texto/imagen de forma especialmente interesante. Lo plástico de las imágenes funciona como prisma que distorsiona el haz de luz textual para convertirlo en una gama de imágenes que se dispersan en un movimiento centrífugo. «Sin título» es el trabajo al alimón de José García Torrego (texto) y María Abellán Hernández y vuelve a ser un magnífico ejemplo de que texto e imagen generan su propia inercia trabajando conjuntamente. La contenida narración silente de una muchacha que se convierte en madre no está sugerida en el contenido textual pero genera otra capa de significado sobre él que lo enriquece, lo contamina con otra lectura; al mismo tiempo el texto ofrece una potencia emocional que estaba atemperada en el grafismo del dibujo. A veces parece existir una brecha más visible entre texto y apartado gráfico como en el caso de Alicia Villares y Rubén Koyra. El minimalismo lírico busca en el apartado gráfico un incipiente recorrido narrativo basado en la anécdota. El texto, como enigma, queda alojado en la última página del cómic. Otras veces el dibujo parcela el texto con serie de imágenes, como es el caso del texto cierra el volumen «Fantasma en el aire»- en el que el mundo vegetal, las estancias vacías y un rostro desdibujado son herramientas suficientes para dialogar con el contenido del poema de una forma muy fidedigna trazando una imaginería que habla perfectamente de las ausencias.

Ese carácter anfibio, como se ha visto, plantea inercias de muy variado alcance: llama la atención que el apartado gráfico no sirva solo como una concreción del material textual. Lejos ya de esas jerarquías que imponían una prevalencia de la palabra sobre la imagen, el grafismo a lo largo de estas páginas impone brechas al texto, lo retuerce, lo vuelve -incluso-ilegible por saturación plástica: el ojo tira del intelecto con una fuerza centrífuga en el que cada imagen pugna por evadirse a su propio territorio. Es tentador establecer 
una doble lectura, o incluso triple en el que se tenga en cuenta cada lenguaje por separado y, también, en conjunto. Sin duda alguna la comparación de esas experiencias resulta perturbadora por lo diferente.

En definitiva la lectura de este libro plantea una experiencia intensa y gozosa con ejemplos magníficos que permiten ver ahora la forma de aunar aquellos lenguajes que caminaban aparentemente separados. La potencia visual de la poesía genera fácilmente una traducción que puede ser expandida en forma de cómic. Por otro lado, ya sabíamos desde hace un tiempo que la narración gráfica había hecho saltar de sus goznes acomodaticios un lenguaje que, presumíamos y ahora sabemos, es sumamente sofisticado y que, durante mucho tiempo, estuvo domesticado en los confines de la cultura de masas. Allí produjo ejemplos magníficos pero esa revolución que de unos años a esta parte está protagonizando enseña su potencial expresivo. Hay que congratularse de que el proyecto Duplex aterrice en España. Lo hace de la mano de dos buenos estudiosos y de un editor que merece un aplauso. El diseño editorial, nada fácil, es una marca más de calidad y la idea de incluir los textos al final del volumen, tanto en español como en inglés, es muy de agradecer. Al goce estético de la lectura hay que superponerle el interés también por enfrentar al cómic a un fenómeno como es lo lírico: cabe abrir un camino para iniciar una reflexión teórica en torno a este aspecto. Estos ejemplos son un buen inicio para abundar en esta labor. 